\title{
MERGER AND DIVISION - A CASE STUDY
}

\author{
Anita Kwartnik-Pruc, PhD \\ AGH University of Science and Technology \\ e-mail:akwart@agh.edu.pl
}

\begin{abstract}
Administrative proceedings regarding the approval of a draft property division are governed by the provisions of the Real Estate Management Act. On 22 September 2004, under the provisions of the Act of 28 November 2003 amending the Real Estate Management Act as well as some other acts (Journal of Laws No. 141, item. 1492), the text of the Real Estate Management Act was supplemented with article $98 \mathrm{~b}$, which states that "the owners or perpetual users of the properties shaped in a way that hinders their rational development may submit a joint application on their merger and re-division into parcels of land, if they are entitled to uniform rights to those properties".

This provision introduces detailed regulations regarding the necessary conditions for a merger and division: a commitment to carry out an exchange procedure in the form of a notarial deed, uniformity of the rights to the property, a conditional decision to approve the merger and division, and the need to convey the rights to the property within the date specified in the decision. Municipalities encourage this type of activity, that is conducting local mergers and divisions, because it does not engage them directly. The municipality does not finance these proceedings and there is no obligation to build the necessary technical infrastructure, as is the case in the event of a merger and division of a property. Problems with the implementation of merger and division procedures contained in the example analyzed in this article prompted the author to a deeper analysis of the regulations of article $98 \mathrm{~b}$ of the Act on Real Estate Management, which revealed them to be insufficient. The legislature assumed that a property is created as a result of a merger, which will then be divided into plots of land. However, a merger implemented in such a way, at an intermediate stage, results in the emergence of a plot of land labeled as one record parcel, the individual parts of which belong to different entities and are disclosed in different land and mortgage registers. The plot is recorded both in the mortgage register and in the land registry. Based on the analysis of a specific case, practical problems were presented, regarding determining the content of the regulation and the decision issued during administrative proceedings, associated with the formulation of a notarial deed of the obligation to carry out the exchange procedure and the exchange itself as well as the disclosure of the merger and division in land and mortgage registers. Sources of the problems were identified and supplementation of insufficient legal regulations was proposed.
\end{abstract}

Keywords: property, division, merger and division.

JEL Classification: R52.

Citation: Kwartnik-Pruc A., (2013), "Merger and division - a case study", Real Estate Management and Valuation, vol. 21, no. 2, pp. 37-44.

DOI: $10.2478 /$ remav-2013-0015.

\section{Introduction}

On 22 September 2004, under the provisions of the Act of 28 November 2003 amending the Real Estate Management Act as well as some other acts (Ustawa 2003), the text of the Real Estate Management Act was supplemented with article $98 \mathrm{~b}$, which states that "the owners or perpetual users of the properties shaped in a way that hinders their rational development may submit a joint application on their merger and re-division into parcels of land, if they are entitled to uniform rights to those properties". In accordance with the views presented in the available literature, this regulation is to facilitate the 
implementation of a procedure for merging properties and re-dividing them into new parcels of land in a way that improves the existing structure, to their owners or perpetual users (BOJAR 2008, BIENIEK ET AL. 2008, WOLANIN 2011). This procedure, according to (BIENIEK ET AL.), allows the owners (perpetual users) of the property to avoid a formalized unification procedure, which is long-lasting, and involves proceedings which municipalities are often not interested in conducting due to the necessity of their implementation by municipal authorities as well as a municipal obligation to build the necessary technical infrastructure.

The reason for writing this article are problems in the practical implementation of the provisions of article $98 \mathrm{~b}$ of the Act on Real Estate Management signaled by employees of the municipality administration, as well as the author's personal experience in this field.

\section{Acceptability conditions for merger and division, defined in the Act on Real Estate Management}

In article $98 \mathrm{~b}$ of the Act on Real Estate Management, the legislature clearly stated the conditions for the acceptability of this process. These are:

- the impossibility to rationally develop the owned properties,

- a joint application submitted by all the owners or perpetual users of the properties covered by the application for a merger and division,

- the homogeneity of the rights to the properties subject to the proceedings,

- the obligation to attach to the application for a merger and division a commitment to the reciprocal conveyance of rights to parts of their properties that were included within the newly parcelled out plots of land, by the owners or perpetual users, prepared in the form of a notarial deed.

The possibility of additional payments in a situation of unequal values of the exchanged properties was allowed. The following legal provisions were indicated as necessary to be applied in these proceedings: article 93 (compliance of the property division with the local zoning plan), article 94 (property division in the absence of a local zoning plan), article 96 and article 97 sections 1-2 (procedure for the division of property), article 98 (land parceled out for roads), article 98a (adjacent fees) and article 99 (access to a public road through the establishment of easements) of the Real Estate Management Act. Thus, in the implemented procedure, all the basic conditions for the acceptability of the division, e.g., access of the newly designed parcels to a public road or compatibility of the proposed division with the conditions of the local zoning plan were to be accounted for. A detailed discussion of the property division procedure itself has been presented in numerous studies (BIENIEK ET AL. 2008; BIEDA, HANUS 2010, BOJAR 2008, DURZYŃSKA 2011, JAWORSKI ET AL. 2011, KARABIN 2012; KWARTNIK-PRUC, RUCHLEWICZ 2006; KWARTNIK-PRUC 2012, ŹRÓBEK ET AL. 2012) and is not the subject of this article.

In most studies, a discussion on merger and division procedures is limited to enumerating the conditions which are necessary for the implementation of the process, set out in the Real Estate Management Act (BIENIEK ET AL. 2008; BOJAR 2008; DuRZYŃSKA 2011; HorosZKO, PĘCHORZEWSKI 2010; JAWORSKI ET AL. 2011, ŹRÓBEK ET AL. 2012) and outlined above. Even studies that analyze the provisions of article 98b in greater detail (KOPYRA 2006, WOLANIN 2011) focus on the correct interpretation of the provision itself and in no way refer to its practical implementation. The scope of an administrative authority's competence is analyzed in terms evaluating the impossibility to utilize a given property in a rational manner and the possibility of rational development of the planned properties (KOPYRA 2006), or the status of an agreement imposing an obligation to exchange properties (KOPYRA 2006, WOLANIN 2011). However, it has not been specified anywhere how to, for example, identify those property parts that have become a part of newly parceled out plots of land, when the division project is developed on the merged area of all the properties under consideration. Hence, the need for the analysis of article $98 \mathrm{~b}$ arose, in terms of the possibilities of its practical implementation, taking into account activities carried out by administrative authorities, surveyors, and notaries.

\section{Analysis of article $98 \mathrm{~b}$ of the Act on Real Estate Management in terms of its practical implementation}

The issue that comes to the forefront is determining the subjects of merger and division procedures at every stage of their implementation. According to M. Wolanin (WOLANIN 2011), as a result of the proceedings on mergers and divisions, the abolition of cadastral boundaries between properties occurs, and as a result of a subsequent division, new boundaries of existing properties are defined. 
Taking this view, it should be noted that during a merger and division, the abolition of cadastral boundaries between the properties in question takes place. The surveyor develops a property division plan for the area marked by the external boundaries of the area concerned. However, a problem which has been completely overlooked in all previous publications is that we still have to deal with separate properties. These are properties belonging to different entities and are generally disclosed in separate land and mortgage registers. A land and mortgage register is conducted for a specific property, in this case a particular piece of land. The scope of ownership rights or entitlement to perpetual usufruct of a given property is defined by the boundaries of that property. Since the decision on the merger and division does not interfere with property ownership subject to the proceedings, how is it possible to merge separate properties, belonging to different entities and disclosed in separate registers, into one record parcel? As defined in $\$ 9$ section 1 of the Regulation of the Minister of Regional Development and Construction of 29 March 2001 on the register of land and buildings (ROZPORZĄDZENIE 2001a), a record parcel is a continuous area of land located within a single precinct, legally homogeneous, and parceled out by means of boundary lines. The abolition of property boundaries in effect leads to the emergence of a parcel comprised of different properties, which is in conflict with the aforementioned definition. Although such a plot is at an intermediate stage of the proceedings, it is recorded in both the mortgage register and in the land registry, as keeping both of these registers assumes continuity of information about the plot. Assuming that each of these properties is disclosed in a separate land and mortgage register, how can their merger be disclosed into one record parcel in those registers?

Another problem which occurs in practice refers to determining the parts of properties which became part of the newly parceled out plots of land. Pursuant to the provisions of article $98 \mathrm{~b}$ section 3 , the division of a property "shall be conducted on condition that the owners or perpetual users make, by way of exchange, reciprocal conveyance of the rights to a part of the property that became part of the newly parceled-out plots of land". If this procedure is to merge properties into one record parcel and then divide it into areas allowing for their rational development (Fig. 1), it is not possible to determine which area of the original property has been used to create a new plot.
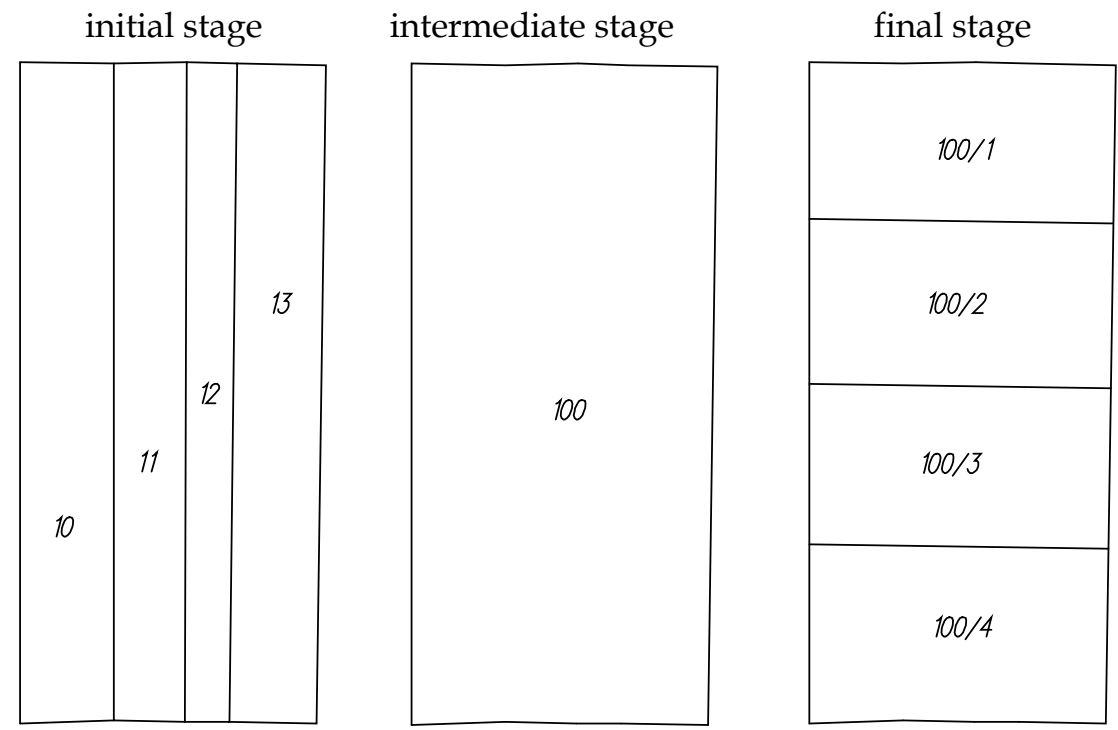

Fig. 1. Properties, subject to the proceedings disclosed in the documentation, at each stage of the merger and division. Source: own study

Pursuant to $\S 36$ of the Ordinance of the Minister of Justice of 17 September 2001 on land and mortgage registers and collections of documents (ROZPORZĄDZENIE 2001a), a part of a property can be parcelled out only if documents are submitted, which are the basis to label the property both as to the parcelled out part and as to the remaining part. Such data does not exist in the geodetic documentation of these proceedings. Therefore, in the proceedings of the merger and division, there is no possibility to explicitly indicate, neither in an exchange agreement nor in the land and mortgage register, the part of the property being the subject of the exchange agreement.

Another important issue is the acceptability of the changes in the ownership structure of the properties subject to the proceedings, regarding the merger and division. M. Wolanin (WOLANIN 2011) 
allows for the parceling out of more plots of land in a single property, but at the same time believes that, as a result of the merger and division, more properties than the number included for the merger cannot be parcelled out. He also finds it unacceptable to parcel out such plots of land which are to be the subject of joint ownership from these properties, if there were no such properties prior to the merger, as this procedure does not change the existing structure of property ownership. It is difficult to agree with this position. In literature, the opinion that a merger and division is supposed to constitute a simplified procedure of merging and dividing is repeatedly quoted.

According to the author, the uniformity of property rights required for these proceedings stems from difficulties in determining the value of various rights to the property and is designed to simplify the procedure. The primary objective of the proceedings is, however, to improve the structure of the land. M. Wolanin (WOLANIN 2011) also points out that the purpose of the proceedings is the rational development of the property, in accordance with planning documents. Often, the procedure for a merger and division is required by long and narrow plots which lie adjacent to a road on their shorter side. In such a case, how can one provide the newly parceled out plots with access to a public road? This is best accomplished by designing an internal road, of which each of the parties have their share. Since the change of the legal status of the property in these proceedings is made through a voluntary civil law agreement, such a limitation seems unreasonable.

\section{Analysis of a sample merger and division procedure}

The below analyzed example also contributed to the carrying out of the study. It is the only procedure of this type carried out in the district of Krakow. An inquiry to two other geodetic and cartographic documentation centers revealed that not a single case of a merger and division had been conducted within their operating area.

The sample procedure covers three properties located next to each other. They are narrow plots of an elongated shape (Fig. 2) with the shorter side adjacent to a public road. These properties were disclosed in the register of land and buildings as arable land - arable land class IV a. Each of these properties was recorded in a separate land register. According to the local zoning plan, the concerned properties are situated mainly in the area marked MU3 - zoned for residential and commercial service development, where the minimum area of newly parceled land out is 1,000 $\mathrm{m} 2$. From the side of the road, a narrow strip of land, KDL2 - communication areas, was intended for widening the local road.

These properties were owned by individuals and were free of the rights and claims of third parties. At the request of the property owners, an authorized surveyor prepared a preliminary plan of the merger and division. As part of the initial division plan, three parcels were merged into one and then divided into five parcels, including one as the access road (Figure 2).

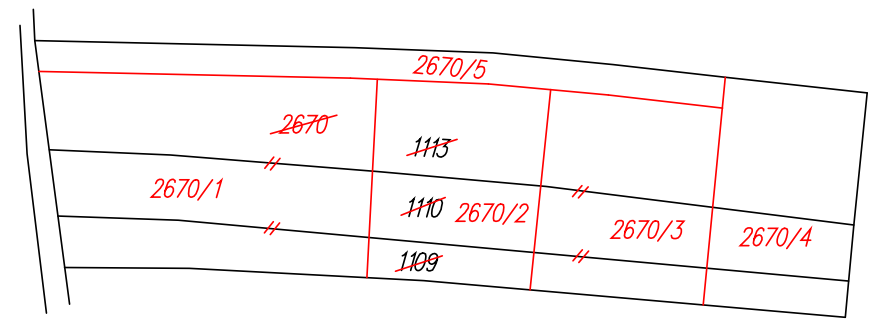

Fig. 2. Concept of the merger and division in the analyzed example. Source: own study, based on materials obtained from the District Center for Geodetic and Cartographic Documentation in Krakow.

Therefore, as discussed above, we were dealing with a situation when one record parcel covers the area of three parcels of land belonging to three different owners and having separate land and mortgage registers.

Based on a draft design of the division, the notary prepared an agreement obliging to carry out an exchange, in the form of a notarial deed, in accordance with article $98 \mathrm{~b}$ sections 1 and 3 of the Act on Real Estate Management. Under those provisions, it is necessary to specify those parts of the properties which became part of the newly parceled out plots of land, both in the preliminary agreement and the final agreement. Based on the geodetic documentation drawn up by a land surveyor, in accordance with the regulations of art. $98 \mathrm{~b}$, such a specification was impossible. In the analyzed example, the notary public prepared a preliminary agreement, according to which the parties were going to exchange not physical pieces of real estate (which had not been parceled out), 
but rather become the co-owners of the three properties and thus convey upon each other the shares to the properties prior to the merger, to be followed by the dissolution of ownership. Individual shares were determined on the basis of the area of the parcels disclosed in the land-use changes in the preliminary division design and the share in the internal access road. The solution of the problem of merging three properties into one record parcel by unifying the rights to the entire area put forward by the notary public demonstrates the notary's vast knowledge and experience. This solution, however, despite being in accordance with the law, complicates rather than simplifies the whole process of merger and division. Firstly, it requires the new co-owners and their shares to be recorded in all land and mortgage registers, then the property to be transferred into one register to catalog the merger, followed by the division of the property and, finally, the dissolution of the ownership to be disclosed by establishing new land and mortgage registers.

Subsequently, upon the request of the owners, on the basis of the draft property division and the preliminary agreement in the form of a notarial deed, the Mayor positively assessed the division design of the three parcels earlier merged into one property (the wording of the decision). From the legal point of view, the wording is incorrect, as in fact we are still dealing with three separate properties, disclosed in separate registers.

Based on the draft division of the property which had received a positive opinion, an authorized surveyor conducted field proceedings and then developed technical documentation. The documentation included a map complementing the merger of the parcels. In the description of the changes, it was pointed out that the three parcels merge and are given a new number. Three parcels, which are separate properties as disclosed in three land and mortgage registers, belonging to three different owners, are merged into a single parcel. This map was accepted into the national geodetic and cartographic resource and received a clause that, under article 21 of the Surveying and Mapping Law (UsTAWA 1989), this document serves as the basis for making an entry in the land and mortgage register. As explained above, it is not possible in the light of the applicable law to disclose such a status in land and mortgage registers. Another map included in the technical documentation - a map with the draft division of one parcel covered by the three land and mortgage registers, was also labeled with a clause that it is the basis for the entry in the land and mortgage registers. The map, as well as the whole appraisal study, was admitted to the state geodetic and cartographic resource.

Based on the appraisal study admitted to the state geodetic and cartographic resource, the Mayor, by way of an administrative decision (the wording of the decision):

1) approved the merger of the three properties into a record parcel,

2) approved the division of this single parcel into 5, provided that:

a) in order to dissolve the co-ownership, the co-owners conduct the reciprocal conveyance of property rights to the newly parceled out plots by way of an exchange,

b) when selling the parceled out plots, easements will be established for each and every owner and all of their successors in title, or the sale will be combined with the sale of a share in the parcel which is the internal access road.

To convey the rights to the parceled out plots, the Mayor appointed a period of 4 months as of the day on which the decision becomes final.

Due to the fact that the decision approving the merger and division does not result in any ownership changes, it is difficult to agree with the correctness of the statement that the Mayor approves the merger of the three properties into one parcel. The second remark relates to clause $2 \mathrm{a}$. At the time of the issuance of the decision, parties to these proceedings were not co-owners, but each of them was the sole owner of his or her property.

On the grounds of the Mayor's final decision regarding the merger and division approval, the notary public prepared an appropriate exchange agreement and the dissolution of ownership, according to the solution presented in the preliminary agreement. The owners of individual properties mutually conveyed their shares upon each other (exchange) and then conducted the dissolution of ownership in such a way, that each of them had become the sole owner of a parceled out plot. The notarial deed also included the property owners' request that the district court shall:

1) on the basis of this agreement and the attached documents, merge the properties covered by separate land and mortgage registers into one of them, enter the merger of the parcels into one parcel, and then enter its division,

2) after the disclosure of the division, establish separate land and mortgage registers for all the 
parcels, except for the parcel which is the internal access road, indicating their respective owners,

3) in the land and mortgage register, in which the parcel constituting the internal access road remained, enter its shares in section II, as it was stipulated in the agreement.

The analysis of land and mortgage registers covering the merger and division revealed that the court implemented the request contained in the notarial act word for word, while ignoring the very content of the agreement, i.e., the conveyance of the shares. Without disclosing the co-ownership, two properties were transferred to the land and mortgage register of the third owner, in which the merger and the division were then disclosed and finally, new land registers for the parceled out plots were established and the new co-owners of the parcel constituting the internal access road were entered. The author did not manage to clarify the reasons for the court taking such action. Nevertheless, regardless of the reasons, a situation which was unacceptable from the legal point of view occurred in these proceedings - properties owned by different entities were merged in one land and mortgage register. It also demonstrates problems regarding the disclosure of such complicated agreements in registers.

\section{Conclusions}

The merger and division of properties is a rarely carried out procedure. This is largely due to the difficulties identified within this article. The problems that occurred during the implementation of the presented case prompted the author to carry out a deeper analysis of the provisions of article $98 \mathrm{~b}$, allowing the general sources of problems with the implementation of the merger and division procedures to be identified and possible solutions to be proposed.

In a situation where the owners of neighboring properties, which are shaped in a way that hinders their rational development, want to improve their configuration, the surveyors carry out a procedure of property division that is simple in practice. The division plan is developed in such a manner that the existing boundaries are crossed by the newly designed ones. However, a kind of "grid" is created which allows the parts of the divided property which will be included in the new property to be easily identified. There are no problems with the disclosure of such a division of an individual property in land and mortgage registers. Moreover, there are no problems with identifying the parts of the property which became part of the newly parceled out plots of land in the exchange agreement. In such proceedings, the applicants are all the owners (co-owners) who are committed to creating new properties of the parceled out parts, the shape and size of which will be consistent with the specifications of the local zoning plan. Such action unnecessarily multiplies entries in land registers and forces the owners to carry out one more separate proceeding after concluding the exchange agreement - the merger of the parcels, which should also be disclosed in the land registers. Nevertheless, according to the author who is a qualified surveyor, this is the best of the possible solutions in the current state of the law.

Introducing the regulations contained in article $98 \mathrm{~b}$ was aimed at the owners of properties shaped in a way that hinders their rational development, to facilitate parcel configuration changes so that it would be possible to develop them in accordance with the settlements of the local zoning plan. In a commentary to the Act on Real Estate Management (BIENIEK AT ALL 2008), it is said that the discussed solution is a nucleus of a good design to meet the expectations and improve the hitherto structure of the existing property. Although the author believes this to be the case, he also feels that the regulations contained in article $98 \mathrm{~b}$ are insufficient for the procedure of a merger and division to be widely implemented. Below, the author presents her own proposal to amend and supplement article $98 \mathrm{~b}$, which would allow the above presented problems to be eliminated.

The first issue that should be addressed is removing the intermediate step in the merger and division process. The scope of these proceedings should not include parceling out the plot which is the result of the merger of properties, as in the case of the merger and division as well as the merger and land exchange. The property division plan should present the final outcome of the proceedings, with only an indication of the target properties and the owners of newly parceled out plots, according to a preliminary agreement (Fig. 3).

This requires an amendment to section 3 of article $98 \mathrm{~b}$ of the Act on Real Estate Management. The preliminary agreement and the final exchange agreement should only specify which original property is exchanged for which newly parceled out plot. 
initial stage

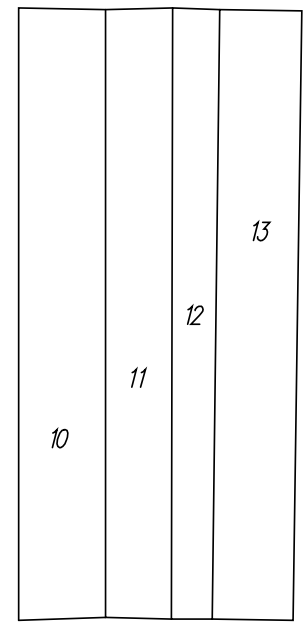

final stage

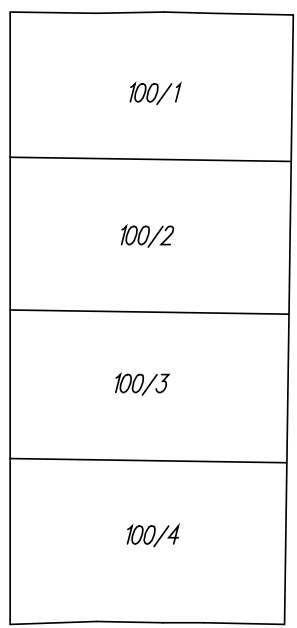

Fig. 3. Real properties subject to the modified procedure with the proposed changes, presented in the documentation at each stage of the merger and division. Source: own study

The adoption of this solution also requires article $98 \mathrm{~b}$ to be expanded regarding the disclosure of the results of such proceedings in land and mortgage registers. According to the author, a solution applied in both merger proceedings should be included here, i.e., a provision allowing for the closure of the land and mortgage register for the original property, and establishing ones for the new property, in accordance with $\S 36$ of the Ordinance of the Minister of Justice of 17 September 2001 on land and mortgage registers and collections of documents (ROZPORZĄDZENIE 2001b).

Taking the proposed changes into consideration by the legislature would allow for: reducing the amount of documentation developed by a surveyor, simplifying administrative proceedings, simplifying the preliminary and final agreements and limiting the number of entries in land registers. It would also encourage property owners to improve the spatial structure of properties shaped in a way that hinders their rational development.

The study has been carried out with financial support from the statutory research No 11.11.150.005 AGH University of Science and Technology.

\section{Bibliography}

BiEnIEK G., KAluS S., MARMAj Z., MZYK E., 2008, Ustawa o gospodarce nieruchomościami, Komentarz, LexisNexis, Warszawa.

BIEdA A., HANUS P., 2010, Determination of Real Estate Boundaries for the Purposes of Subdivision Process, Geomatics And Environmental Engineering, vol. $4 \mathrm{nr} 1$.

BojAR Z., 2008, Podziaty nieruchomości, Wydawnictwo Gall, Katowice.

DURZYŃSKA M., 2011, Podział Nieruchomości, LexisNexis, Warszawa.

HoroszKo M., PęCHORZEWSKi D., 2010, Gospodarka nieruchomościami, Komentarz, C.H. Beck, Warszawa.

JAWORSKI J., PRUSACZYK A., TUŁODZIECKI A., WOLANIN M., 2011, Ustawa o gospodarce nieruchomościami, Komentarz, C. H. Beck, Warszawa.

KARABIN M., KARABIN M., 2012, Problematyka przyjęcia granic nieruchomości do podziału w aspekcie jednolitości wykonywania prac geodezyjnych, Studia i Materiały Towarzystwa Naukowego Nieruchomości, vol. 20, nr 4.

KOPYRA J., 2006, Połaczenie i ponowny podziat nieruchomości gruntowych uksztattowanych w sposób uniemożliwiajacy ich racjonalne zagospodarowanie, Rejent 2006, nr 12.

KWARTNIK-PRUC A., RUCHLEWICZ B., 2006 Rola decyzji o warunkach zabudowy i zagospodarowania terenu w procesie podziału nieruchomości, Geodezja: Półrocznik Akademii Górniczo-Hutniczej im. Stanisława Staszica w Krakowie, vol. 11 nr 2.

KWARTNIK-PRUC A., 2012, Influence of spatial planning in Poland on property division , FIG COMMISSION 3, JOINT FIG/UN ECE WORKSHOP, https://sites.google.com/site/figcom3athens2012/proceedings-1, 13.01.2013

RozPORZĄDZENIE Ministra Rozwoju Regionalnego i Budownictwa z dnia 29 marca 2001 r. w sprawie ewidencji gruntów i budynków (Dz. U. Nr 38, poz. 454). 
ROZPORZĄDZENIE Ministra Sprawiedliwości z dnia 17 września 2001 r. w sprawie prowadzenia ksiag wieczystych i zbiorów dokumentów (Dz. U. Nr 102, poz. 1122).

UstAWA z dnia 17 maja 1989 r. Prawo geodezyjne i kartograficzne (Dz. U. z 2010 r. Nr 193, poz. 1287 z późn. zm.).

USTAWA z dnia 21 sierpnia 1997 r. o gospodarce nieruchomościami (Dz. U. z 2010 r. Nr 102, poz. 651 z późn. zm.).

USTAWA z dnia 28 listopada 2003 r. o zmianie ustawy o gospodarce nieruchomościami oraz o zmianie niektórych innych ustaw (Dz. U. Nr 141, poz. 1492).

WolAnin M., 2011, Połaczenie nieruchomości w celu ponownego ich wydzielenia, Nieruchomości, C.H.Beck, nr 11.

ŹRÓBEK S., ŹRÓBEK R., KURYJ J., 2012, Gospodarka nieruchomościami, Wydawnictwo Gall, Katowice. 